\title{
Meningkatkan Aktivitas Dan Hasil Belajar PKn Peserta Didik KelasVIII.D Semester Ganjil Tahun Pelajaran 2016/2017 Melalui Strategi Think Pair Share Dengan Media Make A Match Di SMP Negeri 16 Mataram
}

\author{
Katmi Wahjuni \\ guru PKn di SMP Negeri 16 Mataram, Kota Mataram
}

\begin{abstract}
Abstrak. Tujuan penelitian ini adalah untuk mengetahui efektifitas model pembelajaran Think Pair Share ( TPS ) Plus Make a Mach dalam meningkatkan aktivitas dan hasil belajar peserta didik pada mata pelajaran PKn . Dengan penelitian ini diharapkan dapat memberikan manfaat bagi peserta didik, guru maupun sekolah. Hasil penelitian pada siklus pertama, proses pembelajaran mengalami beberapa kendala meskipun berjalan sesuai skenario pembelajaran yang direncanakan, namun aktivitas guru dalam menerapkan model pembelajaran TPS Plus hanya mencapai skor 19 dari 32 skor maksimal ( 59,38 \% ) tahapan pembelajaran dengan kategori cukup aktif .Dan aktivitas belajar siswa hanya mencapai skor 20 dari 32 skor maksimal $(62,5 \%)$ dengan kategori cukup aktif. Hasil evaluasi (hasil belajar) siswa hanya mencapai $54,55 \%$ siswa yang tuntas belajar (nilai $\geq$ KKM). Sedangkan pada siklus kedua proses pembelajaran berjalan dengan lancar dan menyenangkan sesuai skenario pembelajaran yang diharapkan, dimana aktivitas guru dalam menerapkan model pembelajaran TPS Plus telah mencapai skor 29 dari 32 skor maksimal yang telah ditetapkan $(90,63 \%)$ dengan kategori sangat aktif. Dan aktivitas belajar siswa telah mencapai skor 28 dari 32 skor maksimal $(87,50 \%)$ dengan kategori sangat aktif. Hasil belajar (hasil evaluasi) siswa juga megalami peningkatan yang mencapai kriteria ketuntasan kelas sampai 93,68 dan telah 95\% siswa mendapat nilai tuntas (nilai $\geq$ KKM).
\end{abstract}

Kata Kunci: Aktivitas , Hasil Belajar dan Model Pembelajaran Think Pair Share (Tps) Plus (Divariasikan Dengan Model Pembelajaran Make A Match)

\section{PENDAHULUAN \\ Latar Belakang}

SMP Negeri 16 Mataram adalah salah satu sekolah menengah pertama yang berada di pinggir Kota Mataram, yang berasal dari latar belakang keluarga dan kondisi lingkungan anak yang beraneka ragam. Keaneka ragaman itulah yang menimbulkan berbagai permasalahan pendidikan yang mendasar, khususnya dalam proses pembelajaran dan dukungan kegiatan belajar mengajar untuk mata pelajaran PKn.

Berangkat dari Kurikulum Tingkat Satuan Pendidikan (KTSP) di atas, maka pendidik dalam hal ini guru hendaknya mampu mengemban beban profesi yang melekat dalam tugasnya atau dengan kata lain guru harus benar-benar kompeten dalam bidangnya sehingga pelaksanaan proses pembelajaran di kelas dapat berjalan dengan maksimal dan mencapai hasil yang tinggi. Terutama dalam sistem pengelolaan kelas agar kelas menjadi hidup dan semangat dalam belajar maksimal dan komunikatif.

Namun pada kenyataannya masih banyak sekolah yang menerapkan pembelajaran konvensional yang dikarenakan masih adanya beberapa faktor yang mempengaruhi diantaranya faktor guru pengajar, faktor peserta didik yang belajar, keadaan sekolah dan dukungan orang tua dan masyarakat sekitarnya.

Pada tahun pelajaran yang lalu, KKM untuk mata pelajaran PKn kelas VIII semester ganjil yang ditentukan 75,0 (tujuh puluh lima). Ada beberapa permasalahan yang sering ditemui selama aktivitas pembelajaran yang mengakibatkan rendahnya hasil belajar peserta didik, diantaranya :

1. Input peserta didik yang sangat rendah, dalam mengikuti proses pembelajaran peserta didik cendrung bersikap pasif, peserta didik yang tidak ada gairah belajar, banyak peserta didik yang ribut dan keluar masuk kelas seenaknya, banyak peserta 
didik yang senang ngobrol sendiri yang tidak berhubungan dengan materi pelajaran PKn.

2. Aktifitas Kegiatan Belajar Mengajar masih didominasi oleh guru, kebanyakan

peserta didik hanya menerima, mencatat dan melaksanakan aktifitas pembelajaran

sesuai dengan yang diperintahkan guru (peserta didik kurang kreatif dan aktif).

3. Metode Pembelajaran yang digunakan oleh guru kurang bervariasi, cendrung hanya menggunakan metode konvensional (ceramah , tanya jawab dan penugasan), akibatnya pembelajaran kurang menarik dan membosankan.

4. Penggunakan media pembelajaran (alat peraga, alat bantu dan sumber belajar yang

lain) oleh guru kurang optimal. Karena itu peserta didik mengalami kesulitan untuk

memahami konsep- konsep materi yang diajarkan.

5. Pelaksanaan uji Kompetensi untuk setiap Kompetensi Dasar (KD) yang materinya

telah diajarkan menunjukkan hasil yang tidak menggembirakan karena sebagian

besar nilai uji kompetensi peserta didik masih di bawah KKM, sehingga banyak

sekali peserta didik yang harus mengikuti kegiatan remedial.

Berdasarkan

permasalahanpermasalahan yang sering ditemui dalam pembelajaran PKn di SMP Negeri 16 Mataram diperlukan suatu upaya untuk meningkatkan partisipasi peserta didik dalam pembelajaran sehingga hasil belajar peserta didik pada mata pelajaran PKn dapat ditingkatkan. Upaya peningkatan partisipasi (aktivitas) peserta didik ini dilakukan dengan menggunakan metode pembelajaran yang cocok dan sesuai dengan situasi dan kondisi peserta didik di sekolah.

Sehubungan dengan hal di atas peneliti ingin mencoba untuk mengatasi kelemahan tersebut dengan melaksanakan model pembelajaran TPS (Think Pair Share) Plus yang diajukan sebagai suatu Penelitian Tindakan Kelas yang berhubungan dengan penerapan metode pembelajaran kooperatif sebagai alternatif pengganti metode ceramah yaitu "Meningkatkan Aktivitas Dan Hasil Belajar Pkn Peserta Didik Kelas VIII.D
Semester Ganjil Tahun Pelajaran 2016/2017 Melalui Strategi Think Pair Share Dengan Media Make A Match Di Smp Negeri 16 Mataram"

Rumusan Masalah :

Apakah

penerapan

model

pembelajaran Think Pair Share (TPS) Plus dapat meningkatkan aktivitas dan hasil belajar peserta didik KelasVIII D pada mata pelajaran PKn di SMP Negeri 16 Mataram semester ganjil Tahun Pelajaran 2016/2017 .

\section{Tujuan Penelitian.}

Penelitian Tindakan Kelas ini bertujuan untuk :

- Mengetahui aktivitas dan hasil belajar peserta didik pada mata pelajaran PKn khususnya pada materi menampilkan perilaku yang sesuai dengan nilai-nilai Pancasila.

- Mengetahui penggunaan model pembelajaran Think Pair Share (TPS) Plus yaitu model pembelajaran Think Pair Share yang dikombinasikan dengan model pembelajaran make a match.

- Mengetahui dampak penggunaan model pembelajaran Think Pair Share (TPS) Plus untuk meningkatkan aktivitas dan hasil belajar peserta didik kelas VIII D pada mata pelajaran PKn di SMP Negeri 16 Mataram Semester Ganjil Tahun Pelajaran 2016/2017.

\section{Manfaat Hasil Penelitian}

- Peserta didik : a) Untuk meningkatkan hasil belajar peserta didik pada mata pelajaran PKn, b) Sebagai motivasi bagi peserta didik untuk meningkatkan pemahaman secara mandiri terhadap materi pelajaran $\mathrm{PKn}, \mathrm{c})$ Mendorong peserta didik untuk mengembangkan ketrampilan bekerjasama (kooperatif ) dan bersosialisasi dengan teman sebaya dalam belajar, dan d). Memberi latihan berkehidupan kelompok dalam masyarakat.

- Guru : a) Meningkatkan pengembangan model pembelajaran, b). Meningkatkan ketrampilan merencanakan, mengelola dan mengevaluasi proses pembelajaran, c) Menumbuhkan minat ilmiah dalam menjalankan profesi keguruan terutama dalam mengembangkan karya tulis ilmiah. 


\section{KAJIAN PUSTAKA}

\section{Landasan Teori}

\section{Tinjauan tentang Aktivitas Belajar}

Pengertian Aktivitas

Aktivitas berasal dari kata aktif yang artinya giat, bergerak terus (Santoso,2006). Sedangkan aktivitas belajar berasal dari kataaktif dan belajar yang artinya suatu aktivitas dalam kegiatan belajar mengajar. Bila peserta didik telah memiliki aktivitas yang tinggi, maka guru akan lebih senang mengajar dan suasana mengajar lebih baik. Dalam proses belajar mengajar sangat perlu adanya aktivitas peserta didik, karena akan mempengaruhi situasi belajar di samping itu kesungguhan peserta didik sangat menentukan berhasil atau tidaknya kegiatan belajar mengajar ( Hamalik, 2003 ).

\section{Pengertian Belajar}

Belajar dapat diartikan sebagai suatu bentuk pertumbuhan atau perubahan dalam diri seseorang yang dinyatakan dalam cara-cara bertingkah laku berkat pengalaman dan latihan (Hamalik, 2003). Jadi belajar adalah suatu proses perubahan dan pertumbuhan perilaku atau pribadi seseorang berdasarkan praktek atau pengalaman tertentu untuk memperoleh keahlian dan kepandaian sehingga berguna bagi kesejahteraan individunya. Dari uraian tentang teorinya, belajar adalah suatu proses yang dilakukan secara sadar mulai dari sejak lahir sampai mati yang prosesnya secara bertahap sesuai dengan tingkat pikiran yang dimiliki.

Prinsip-prinsip belajar agar para peserta didik aktif dan berhasil

Dalam bukunya Psikologi Pendidikan Hamalik (2003) mengemukakan prinsip belajar aktif sebagai berikut :

a. Pengalaman Dasar

Pengalaman dasar peserta didik berfungsi mempermudah peserta didik memperoleh pengalaman baru. Peserta didik merasa sulit memahami suatu generalisasi jika peserta didik belum mempunyai suatu konsep sebagai pengalaman dasar. Pengalaman dasar ini dapat diperoleh melalui kegiatan-kegiatan membaca, mendengar, cerita observasi, acara televisi dan karya wisata.

b. Motivasi belajar
Motivasi belajar diberikan kepada peserta didik agar peserta didik melakukan perbuatan belajar untuk memperoleh pengetahuan, keterampilan dan sebagainya. Dorongan motivasi berguna untuk mendorong mereka belajar secara aktif dan sebagai pemberi arah dalam proses belajar.

c. Penguatan ( latihan dan ulangan ) belajar Hasil belajar yang diperoleh oleh peserta didik perlu dimantapkan agar tercipta penguasaan tuntas. Guru hendaknya memberikan kesempatan kepada peserta didik untuk mengulang dan melatih halhal yang telah dipelajari oleh mereka.

\section{Jenis-jenis kegiatan belajar aktif}

Dalam uraian berikut ini penulis akan menyajikan beberapa klasifikasi kegiatan belajar yang dapat atau seharusnya dilakukan peserta didik.

Curiculum Guiding Comittee of the Winsconsin Cooperative Education Planning Program telah mengadakan klasifikasi tentang kegiatan-kegiatan belajar sebagai berikut :

a. Kegiatan penyelidikan, membaca, wawancara, mendengarkan radio, menonton TV dan alat-alat elektro lainnya.

b. Kegiatan penyajian, laporan panel and round table discussion, mempertunjukkan visual aid, membuat grafik dan chart.

c. Kegiatan latihan mekanis, digunakan bila kelompok menemui kesulitan sehingga perlu diadakan ulanganulangan dan latihan-latihan.

d. Kegiatan apresiasi, mendengarkan musik, membaca, menyaksikan gambar

( Hamalik, 2003 ).

\section{Tinjauan tentang Hasil Belajar}

Pengertian Hasil Belajar

Hasil belajar adalah pola-pola perbuatan, nilainilai, pengertian-pengertian, sikap-sikap, aprisiasi dan keterampilan. Menurut pemikiran Gagne, hasil belajar merupakan :

a. Informasi verbal yaitu kapabilitas mengungkapkan pengetahuan dalam bentuk bahasa baik lisan maupun tertulis. 
b. Keterampilan intelektual yaitu kemampuan mempresentasikan konsep dan lambang.

c. Strategi kognitif yaitu kecakapan menyalurkan dan mengarahkan aktivitas kognitifnya sendiri. Kemampuan ini meliputi penggunaan konsep dan kaidah dalam memecahkan masalah.

d. Keterampilan motorik yaitu kemampuan melakukan serangkaian gerak jasmani dalam urusan koordinasi, sehingga terwujud otomatisme gerak jasmani.

e. Sikap adalah kemampuan menerima atau menolak obyek berdasarkan penilaian terhadap obyek tersebut. Sikap merupakan kemampuan menjadikan nilai-nilai sebagai standar perilaku (Suprijono,2009).

Bloom (Suprijono,2009), berpendapat hasil belajar mencakup kemampuan kognitif, afektif dan psikomotorik. Domain kognitif adalah knowlegde (pengetahuan, ingatan) comprehension (pemahaman, menjelaskan, meringkas, contoh), application (menerapkan), analysis (menguraikan, menentukan hubungan), synthesis (mengorganisasikan, merencanakan, membentuk hubungan baru) dan evaluation (menilai). Domain afektif adalah receiving (sikap menerima), responding (memberi respon), valuing (nilai), organization (organisasi), Charaterization (karakterisasi). Domain psikomotor meliputi initiatory, preroutine dan rountinized. Psikomotor juga mencakup keterampilan prodektif, teknik, fisik, sosial, manajerial dan intelektual. Sementara menurut Lindgren (Suprijono, 2009) hasil pembelajaran meliputi kecakapan, informasi, pengertian dan sikap.

Yang harus diingat, hasil belajar adalah perubahan perilaku secara keseluruhan bukan hanya salah satu aspek potensi kemanusiaan saja. Artinya, hasil pembelajaran yang dikategorisasi oleh pakar pendidikan sebagaimana tersebut di atas tidak dilihat secara fragmentaris atau terpisah melainkan komprehensif.

Faktor-faktor yang mempengaruhi hasil belajar

Hasil belajar merupakan hasil interaksi berbagai faktor, baik faktor internal maupun faktor eksternal. Faktor-faktor tersebut baik secara terpisah maupun bersama-sama memberikan kontribusi tertentu terhadap hasil belajar peserta didik. Faktor-faktor tersebut meliputi :

a. Faktor lingkungan, yang mencakup lingkungan alami, lingkungan sosial budaya.

b. Faktor Instrumental, yang meliputi : Kurikulum, Program, Sarana dan Prasarana, guru.

c. Kondisi Psikologi meliputi : minat, kecerdasan, bakat, motivasi, kemampuan kognitif (Djamarah, 2003).

Tinjauan tentang Model Pembelajaran Think Pair Share (TPS) Plus

Model Pembelajaran TPS (Think Pair Share) Model pembelajaran TPS (Think Pair Share) merupakan cara yang efektif untuk mengubah pola diskusi di dalam kelas. Model ini menentang asumsi bahwa seluruh resitasi dan diskusi perlu dilakukan dalam setting seluruh kelompok. Nurhadi dan Senduk (2003) menyatakan bahwa model pembelajaran TPS memberikan kesempatan kepada peserta didik, waktu untuk berpikir dan merespons serta saling membantu satu dengan yang lain. Guru akan memilih menggunakan model TPS sebagai pengganti metode tanya jawab untuk mengetahui sejauh mana pemahaman peserta didik terhadap materi yang diajarkan setelah guru menyelesaikan penyajian singkat atau setelah peserta didik membaca suatu tugas.

Langkah-langkah dalam penerapan model pembelajaran TPS terdiri dari beberapa langkah, yaitu :

a. Langkah -1 Berpikir (Thinking) : Guru mengajukan pertanyaan berupa isu yang terkait dengan materi yang dibahas dan peserta didik diberi waktu untuk berpikir sendiri selama satu atau beberapa menit untuk memberikan jawaban.

b. Langkah -2 Berpasangan (Pairing) : Guru meminta peserta didik untuk berpasangan dan mendiskusikan mengenai apa yang telah dipikirkan selama beberapa menit (4-5 menit). Interaksi ini diharapkan akan menghasilkan jawaban yang sama dari peserta didik yang berpasangan.

c. Langkah -3 Berbagi (Sharing) : Pada langkah akhir, guru meminta pasanganpasangan untuk berbagi atau bekerjasama 
dengan kelas secara keseluruhan mengenai masalah yang telah didiskusikan. Pada langkah ini akan lebih efektif jika guru berkeliling kelas berpindah dari pasangan yang satu ke pasangan yang lain, sehingga seperempat atau setengah dari pasanganpasangan tersebut memperoleh kesempatan untuk menyampaikan hasil diskusinya.

Lie (1999) menyatakan bahwa jumlah anggota kelompok belajar TPS adalah 2 orang peserta didik (berpasangan), sehingga dalam satu kelas akan terdiri dari beberapa pasang (kelompok diskusi) disesuaikan dengan jumlah siswa dalam kelas yang bersangkutan. Keunggulan utama yang dimiliki oleh model pembelajaran TPS ini adalah dapat meningkatkan partisipasi (keaktifan) siswa dalam menyelesaikan tugas-tugas yang sederhana dan memberikan kesempatan kepada peserta didik untuk memberikan kontribusi dalam diskusi pada kelompoknya masing-masing. Disamping memiliki keunggulan, TPS juga memiliki kelemahan terutama dalam hal jumlah kelompok yang harus dimonitor oleh guru dan jika ada perselisihan dalam kelompok guru agak sulit untuk menengahi karena jumlah kelompoknya terlalu banyak.

\section{Model Pembelajaran Think Pair Share Plus}

Model pembelajaran Think Pair Share Plus adalah model pembelajaran Think Pair

Share yang dikombinasikan dengan model pembelajaran Make a Match (mencari pasangan).

Model Pembelajaran Think Pair Share mempunyai langkah-langkah sebagai berikut :

1. Guru menyampaikan inti materi dan kompetensi yang ingin dicapai.

2. Siswa diminta untuk berfikir tentang materi /permasalahan yang disampaikan guru.

3. Siswa diminta berpasangan dengan teman sebelahnya (kelompok 2 orang) dan mengutarakan hasil pemikiran masingmasing.

4. Guru memimpin pleno kecil diskusi, tiap kelompok mengemukakan hasil diskusinya.

5. Berawal dari kegiatan tersebut, guru mengarahkan pembicaran pada pokok permasalahan dan menambah materi yang belum diungkapkan para siswa.

6. Guru mengajak siswa membuat kesimpulan.

7. Penutup.

Sedangkan model pembelajaran Make-A Match mempunyai langkah - langkah sebagai berikut :

1. Guru menyiapkan beberapa kartu yang berisi beberapa konsep atau topik yang cocok untuk sesi review, sebaliknya satu bagian kartu soal dan bagian lainnya kartu jawaban.

2. Setiap siswa mendapat satu buah kartu.

3. Tiap siswa memikirkan jawaban/soal dari kartu yang dipegang.

4. Setiap siswa mencari pasangan yang mempunyai kartu yang cocok dengan kartunya (soal jawaban).

5. Setiap siswa yang dapat mencocokkan kartunya sebelum batas waktu diberi poin.

6. Setelah satu babak kartu dicocokkan lagi agar tiap siswa mendapat kartu yang berbeda dari sebelumnya.

7. Demikian seterusnya.

8. Guru mengajak siswa membuat kesimpulan.

9. Penutup. (Tukiran, 2013; Depdiknas,2007) Dari langkah-langkah model pembelajaran Think Pair Share dan Make a Match di atas, maka model pembelajaran Think Pair Share Plus merupakan perpaduan dari langkah-langkah kedua model pembelajaran tersebut, sebagai berikut :

1. Guru menyampaikan inti materi dan kompetensi yang ingin dicapai.

2. Siswa diminta untuk berfikir tentang materi /permasalahan yang disampaikan guru.

3. Siswa diminta berpasangan dengan teman sebelahnya (kelompok 2 orang) dan mengutarakan hasil pemikiran masingmasing.

4. Berawal dari kegiatan tersebut, guru mengarahkan pembicaran pada pokok permasalahan dan menambah materi yang belum diungkapkan para siswa.

5. Guru menyiapkan beberapa kartu yang berisi beberapa konsep atau topik yang cocok untuk sesi review, sebaliknya satu bagian kartu soal dan bagian lainnya 
kartu jawaban dan membagikan kepada setiap kelompok pasangan.

6. Setiap kelompok pasangan mendapat satu paket media kartu make a match.

7. Tiap kelompok memikirkan jawaban/soal dari kartu yang dipegang.

8. Setiap kelompok mencari dan memasangkan kartu soal dengan kartu jawaban yang dimiliki.

9. Setiap kelompok yang dapat mencocokkan satu kartunya dengan benar diberi poin.

10. Setelah satu kartu berpasangan dengan benar, maka kelompok tersebut mencocokkan lagi kartu yang berbeda dari sebelumnya.

11. Demikian seterusnya sampai kartu tersebut berpasangan semua.

12. Guru mengajak siswa membuat kesimpulan

13. Guru mengadakan post tes (kegiatan penutup).

\section{Kerangka Berpikir}

Pengajaran dengan model pembelajaran Think Pair Share (TPS) Plus ini, memungkinkan guru memberikan perhatian terhadap siswa serta terjadinya hubungan yang lebih akrab antara guru dan siswa maupun antara siswa dengan siswa. Adakalanya siswa lebih mudah belajar dari temannya, ada pula siswa yang lebih mudah belajar karena harus mengajari atau melatih temannya sendiri.Pengajaran ini memungkinkan siswa lebih efektif memberikan rasa tanggung jawab yang lebih besar, berkembangnya daya kreatif dan sifat kepemimpinan pada siswa serta dapat memenuhi kebutuhan siswa secara optimal.

Dalam hal ini peneliti mempunyai 2 pertanyaan dalam hati, yang mudah-mudahan dapat terjawab dalam Penelitian Tindakan Kelas sekarang ini, yaitu :

1. Seberapa tinggi tingkat aktivitas dan hasil belajar siswa pada mata pelajaran PKn melalui Model Pembelajaran Think Pair Share (TPS) Plus di Kelas VIII. D SMP Negeri 16 Mataram Pada Semester Ganjil Tahun Pelajaran 2016/2017.

2. Bagaimana proses penerapan Model Pembelajaran Think Pair Share (TPS) Plus dalam upaya meningkatkan aktivitas dan hasil belajar siswa pada Mata Pelajaran PKn di kelas VIII. D SMP Negeri 16 Mataram Pada Semester Ganjil Tahun Pelajaran 2016/2017

\section{Hipotesis Tindakan}

Penerapan model pembelajaran Think Pair Share (TPS) Plus dapat meningkatkan aktivitas dan hasil belajar peserta didik kelas VIII. D pada mata pelajaran PKn di SMP Negeri 16 Mataram Semester Ganjil Tahun Pelajaran 2016/2017.

\section{METODE PENELITIAN}

\section{Setting Penelitian}

Sesuai dengan judul penelitian, maka kegiatan Penelitian Tindakan Kelas dilaksanakan di SMP Negeri 16Mataram dalam waktu 3 bulan (dari bulan September sampai dengan November 2016) dengan subyek penelitian adalah peserta didik kelas VIII D yang berjumlah 27 orang pada semester Ganjil Tahun Pelajaran 2016/2017.

\section{Faktor yang diteliti}

- Faktor peserta didik : Mengamati efektifitas pelaksanaan pembelajaran untuk meningkatkan aktivitas dan hasil belajar peserta didik melalui model pembelajaran Think Pair Share (TPS) Plus. Peningkatan aktivitas belajarpeserta didik dapat kita lihat dari : peningkatan hasil pengamatan dan observasi oleh observer terhadap aktivitaspeserta didik pada saat proses belajar mengajar pada siklus II dibandingkan dengan siklus I yang sesuai dengan tahapan pembelajaran model TPS Plus,. Sedangkan peningkatan hasilBelajarpeserta didik dapat kita lihat dari peningkatan rata-rata nilai hasil proses diskusi kelompok TPS Plus dan hasil post tespeserta didik pada siklus II dibandingkan dengan siklus I.

- Faktor guru : Mengetahui cara penyusunan Rencana Pelaksanaan Pembelajaran (RPP) dan tahapan pelaksanaan proses belajar mengajar melalui model pembelajaran Think Pair Share (TPS) Plus pada siklus I dan II.

\section{RencanaTindakan}

Rancangan Penelitian Tindakan Kelas( PTK ) ini akan dilaksanakan dua siklus. Pada setiap siklus berisi tentang : Perencanaan/Planing, (2) Pelaksanaan/Action, 
(3) Observasi/ Observation dan Refleksi /Reflection.

Prosedur Penelitian Tindakan Kelas (PTK) dapat dijabarkan sebagai berikut:

\section{Siklus I}

\section{Perencanaan/Planning}

- Menyusun RPP sesuai dengan model pembelajaran Think Pair Share (TPS) Plus

- Menyediakan da nmembuat alat peraga untuk mendukung kelancaran proses pembelajaran (Kartu absen peserta didik, LKS, kartu soal, kartu jawaban dan media makea match).

- Membuat lembar observasi aktivitas guru, lembar observasi aktivitas peserta didik dan lembar daftar nilai peserta didik yang sesuai dengan pendekatan model pembelajaran Think Pair Share (TPS) Plus.

- Merancang instrument evaluasi pembelajaran (soal post tes pilihan ganda) yang sesuai dengan model pembelajaran Think Pair Share (TPS) Plus.

\section{Pelaksanaan/Action}

Jenis kegiatan yang dilaksanakan pada proses pembelajaran ini adalah Melaksanakan rencana yang telah disiapkan/disusun pada tahap perencanaan.

\section{Observasi/Observation}

- Temansejawat (observer) mengamatitahapan pelaksanaan model Pembelajaran Think Pair Share (TPS) Plus yang telah dilakukan oleh peneliti (dicatat pada lembar observasi aktivitas guru).

- Teman sejawat (observer lainnya) mengamati aktivitas belajar peserta didik (dicatat pada pada lembar observasi aktivitas peserta didik) yang sesuai dengan model pembelajaran Think Pair Share (TPS) Plus.

- $\quad$ Peneliti mencatat dan menganalis hasil belajarpeserta didik (nilai rata-rata hasil proses diskusi TPS Plus dan hasil post tes siswa) di lembar daftar nilai.

\section{Refleksi/Reflection}

- Teman sejawat (observer) menyampaikan hasil pengamatan tahapan pelaksanaan model pembelajaranThink PairShare (TPS) Plus.
- Tanya jawab seputar tahapan pelaksanaan pembelajaran (aktivitas mengajar guru), aktivitas belajar peserta didik dan peningkatan hasil belajar peserta didik selama penggunaan model Think Pair Share (TPS) Plus ini.

- Merekomendasikanhal-hal yang perludiperbaikipadasikluskedua.

\section{Siklus II}

Pada siklus II apa yang dilakukan masih sama dengan siklus I, pada siklus ini lebih difokuskn pada perbaikan dan penyempurnaan saja.

\section{Sumber Data}

- Rencana Pelaksanaan Pembelajaran berisi gambaran global dari materi yang akan disampaikan.

- Instrumen tes digunakan peneliti dalam penelitian ini adalah untuk mengukur pencapaian KKM kelas yang terdiri dari 5 soal permainan pada LKS media make a match untuk diskusi kelompok TPS Plus.

- Lembar observasi: a) Lembar observasi Aktivitas Guru, dan b) Lembar observasi Aktivitas Siswa.

\section{TehnikPengumpulan Data}

a. Data tentang aktivitas belajarpesertadidik diambil dari hasil pengamatan observer terhadap aktivitas belajar pesertadidikdalam mengikuti tahapan pembelajaran model TPS Plus (yang dicatat di lembar Observasi aktivitas pesertadidik).

b. Data tentang penerapan model pembelajaran Think Pair Share (TPS) Plus diambil dari hasil pengamatan observer terhadap aktivitas mengajar guru dalam melaksanakan tahapan pembelajaran model TPS Plus (yang dicatat di lembar observasi aktivitas guru).

c. Data tentang hasil belajar siswa diambil dari (nilai rata-rata hasil diskusi TPS Plus dannilai post tespesertadidik) yang telah mencapai Kriteria Ketuntasan Minimal.

\section{TehnikAnalisis Data}

Data dianalisis dengan pendekatan kuantitatif dan kualitatif. Data kuantitatif yaitu data yang diperoleh peneliti dalam bentuk angka, sedangkan data kualitatifadalah data yang diperoleh dalam bentuk kalimat, gambar atau kata (Sugiyono,2010). 


\section{IndikatorKinerja}

- Aktifitas belajar peserta didik dikatakan meningkat apabila ada peningkatan aktivitas belajar siswa pada siklus II dibandingkan dengan siklus I, dimana aktivitas belajarpesertadidik secara klasikal telah mencapai kategori aktif dari tahapan pembelajaran model TPS Plus.

- Hasil belajar peserta didik dikatakan meningkat apabila ada peningkatan nilai rata-rata kelas (hasil diskusi TPS Plus dan nilai post tes siswa) pada siklus II dibandingkan dengan siklus I, dimana hasil belajar peserta didik yang telah tuntas mencapai $\geq 85 \%$ dari seluruh peserta didik kelas tersebut (sesuai dengan Kriteria ketuntasan kelas).

- Penerapan model pembelajaran Think Pair Share (TPS) Plus dikatakan berhasil apabila peneliti telah melaksanakan $\geq 80$ $\%$ tahapan pembelajaran seperti yang direncanakan dalam RPP.

\section{HASIL DAN PEMBAHASAN PENELITIAN \\ Hasil Penelitian.}

Penelitian ini dilaksanakan pada tanggal 2 sampai 9 September 2016 pada kelas VIII D dengan jumlah siswa 27 orang. Data yang diperoleh pada penelitian ini ada dua macam, yaitu :

a. Data kuantitatif yaitu data yang diperoleh dari hasil evaluasi yang akan memberikan jawaban mengenai berhasil atau tidaknya proses pembelajaran pada mata pelajaran PKn dengan menggunakan model pembelajaran Think Pair Share (TPS) Plus yang diukur dengan peningkatan hasil belajar peserta didik secara klasikal.

b. Data Kualitatif diperoleh dari hasil observasi yang akan memberikan gambaran tentang aktivitas guru dan peserta didik dalam mengikuti tahapan pembelajaran model TPS Plus selama proses belajar mengajar.

\section{Deskripsi Hasil Penelitian Siklus I}

Perencanaan / Planning

Pada tahap ini peneliti telah melakukan beberapa perencanaan yang meliputi pembuatan : Penyusun RPP (lampiran 1), Ringkasan Materi (lampiran 2), Soal post tes (lampiran 3), Kunci Jawaban (lampiran 4), Kartu soal (lampiran 5), Potongan kartu soal make a match (lampiran 6), Lembar Kerja Siswa (lampiran 7), Lembar Observasi Aktivitas Guru (lampiran 8), Lembar Observasi Aktivitas Siswa.

\section{Pelaksanaan / action}

Pada proses belajar mengajar siklus I ini dilakukan observasi kegiatan proses belajar mengajar dengan model pembelajaran TPS Plus. Selama proses belajar mengajar observer mengadakan penilaian aktivitas belajar peserta didik dengan menggunakan lembar observasi aktivitas belajar peserta didik dan mengadakan pengamatan terhadap tahapan pelaksanaan pembelajaran model TPS Plus dengan menggunakan lembar observasi aktivitas guru. Dan peneliti juga mengadakan evaluasi hasil belajar peserta didik dengan menggunakan lembar daftar nilai (nilai ratarata dari hasil diskusi TPS Plus dan hasil post test) untuk mengetahui sejauh mana penguasaan peserta didik terhadap materi yang telah disampaikan. Segala kekurangankekurangan yang terjadi pada siklus I ini akan direvisi dan direfleksi kembali untuk melanjutkan tindakan pada siklus berikutnya.

\section{Hasil Observasi dan Evaluasi.}

- Hasil Observasi peserta didik : berdasarkan hasil yang diperoleh dapat di lihat bahwa dari interval jumlah skor aktivitas belajar peserta didik sebanyak 20 yang terdapat pada interval $18 \leq \mathrm{AS}<22$ dengan kategori cukup aktif.

- Hasil observasi Guru : berdasarkan hasil yang diperoleh dapat di lihat bahwa dari interval jumlah skor aktivitas guru mengajar sebanyak 19 yang terdapat pada interval $18 \leq \mathrm{AS}<22$ dengan kategori cukup aktif. Guru melaksanakan tahapan pembelajaran TPS Plus baru mencapai skor $19 / 32=59,38 \%$.

- Berdasarkan hasil perhitungan ketuntasan diperoleh data bahwa terdapat 62,96\% peserta didik yang tuntas. Hal ini berarti hanya $62,96 \%$ peserta didik yang memperoleh nilai $\geq \operatorname{KKM}(75,0)$.

\section{Refleksi}

Kegiatan refleksi dilaksanakan pada akhir pelaksanaan pembelajaran siklus I. 
Refleksi dilaksanakan oleh peneliti bersama observer dan guru pendamping untuk mengkaji proses pelaksanaan kegiatan siklus I. Bahan yang menjadi acuan dalam melaksanakan refleksi adalah hasil observasi dan evaluasi pada siklus I. Hasil refleksi siklus I diharapkan menjadi dasar perbaikan pada siklus II.

\section{Deskripsi Hasil Penelitian Siklus II Perencanaan / Planning}

Pada siklus kedua ini peneliti lebih menguasai dan lebih sistematis dalam penyusunan RPP (lampiran 13), pembuatan kartu soal (lampiran 18), lembar kerja siswa (lampiran 19), lembar observasi aktivitas guru (lampiran 20), lembar observasi aktivitas siswa (lampiran 21),serta penyusunan alat penilaian sudah sesuai dengan yang direncanakan (lampiran 15). Hal ini karena peneliti benarbenar memperhatikan kesalahan-kesalahan hasil refleksi pada siklus I.

\section{Pelaksanaan / action dan Observasi / observation}

Proses belajar mengajar pada siklus II dilaksanakan pada hari Jumat, tanggal 9 September 2016 dengan materi yang dibahas adalah Menampilkan sikap positif terhadap Pancasila dalam kehidupan bermasyarakat dengan waktu 2 x 40 menit. Pelaksanaan tindakan disesuaikan dengan skenario pembelajaran yang telah dibuat oleh peneliti. Pada siklus ini, selama proses pembelajaran observer mengamati kinerja guru dan peserta didik dalam penerapan model pembelajaran tipe TPS Plus ini, sedangkan guru aktif melaksanakan tahapan-tahapan pembelajaran TPS Plus dan mengadakan penilaian hasil belajar peserta didik yang mencakup hasil diskusi kelompok TPS Plus dan hasil post tes.

\section{Observasi dan Evaluasi}

- Hasil observasi aktivitas siswa : dari interval jumlah skor aktivitas belajar peserta didik sebanyak 28 yang terdapat pada interval $A S \geq 26$ dengan kategori Sangat aktif.

- Hasil observasi Aktivitas Guru : dari interval jumlah skor aktivitas pembelajaran model TPS Plus yang dilaksanakan oleh guru sebanyak 29 yang terdapat pada interval $A S \geq 26$ dengan kategori sangat aktif. Ini berarti guru telah mencapai skor
29/32 atau 90,63\% dari tahapan pembelajaran model TPS Plus.

- Hasil belajar peserta didik pada mata pelajaran PKn yang mencakup dua hal yaitu nilai diskusi kelompok TPS Plus dan nilai hasil post tes dengan presentase ketuntasan sebesar 88,46 \% melampaui Indikator keberhasilan yang ditetapkan.

\section{Pembahasan}

Berdasarkan hasil analisis data tiaptiap siklus, terlihat bahwa hasil dari siklus ke siklus mengalami peningkatan.Pada siklus I, dari hasil observasi dari observer yang ditulis pada lembar observasi aktivitas guru mengajar menunjukkan bahwa aktivitas guru mengajar dengan model pembelajaran TPS Plus masih belum maksimal hanya mencapai skor 19 dari 32 skor maksimal (59\%) dengan kategori cukup baik. Sedangkan hasil observasi dari observer lainnya yang mengamati tentang aktivitas belajar siswa hanya mencapai skor 20 dari 32 skor maksimal yang ditetapkan (62,5\%) dengan kategori cukup aktif. Dan hasil evaluasi (hasil belajar) siswa baru mencapai 82,73 dan kriteria ketuntasan kelas sebesar $54,55 \%$ (peserta didik telah mencapai nilai $\geq \mathrm{KKM}$ 75,0). Ini berarti ketuntasan belajar peserta didik belum tercapai sesuai dengan aktivitas dan ketuntasan hasil belajar menurut standar yang telah ditetapkan (sesuai dengan indikator kinerja). Hal ini disebabkan oleh kesiapan guru dalam menerapkan proses pembelajaran model TPS Plus belum dilaksanakan dengan maksimal dan peserta didik juga kurang kesiapan dalam mengikuti proses pembelajaran model TPS Plus ini, dikarenakan model pembelajaran model TPS Plus ini belum cukup dikenal oleh para guru termasuk peneliti dan peserta didik, sehingga masih banyak kekurangan-kekurangan yang terjadi baik dalam aktivitas belajar peserta didik, aktivitas mengajar guru yang mengakibatkan hasil belajar (nilai rata-rata hasil evaluasi) peserta didik masih rendah.

Berdasarkan hasil analisis pada siklus II yang dilakukan untuk melaksanakan perbaikan-perbaikan yang diusulkan oleh observer pada saat refleksi siklus I, menunjukkan bahwa aktivitas mengajar guru dalam menerapkan model pembelajara TPS 
Plus telah mencapai 29 dari 32 yang telah ditetapkan ( 90,6\%) dengan kategori sangat aktif, sedangkan akitivitas peserta didik mencapai 28 dari 32 skor yang telah ditetapkan peneliti $(87,5 \%)$ dengan kategori sangat aktif pula. Sehingga ini berpengaruh juga terhadap peningkatan hasil belajar peserta didik yangmencapai nilai rata-rata peserta didik 94,0, siswa yang tuntas 18, peserta didik yang tidak tunas 1 orang, dengan persentase ketuntasan kelas sudah mencapai 95\% .Dan bagi peserta didik yang tidak sekolah diberikan tugas remedial (tugas terstruktur) yang sesuai dengan materi yang yang dipelajari. Pada siklus II ini kesiapan peserta didik dalam mengikuti proses pembelajaran dengan menerapkan model pembeajaran tipe TPS Plus sudah sangat baik, perhatian peserta didik sudah mulai terfokus, saat diskusi peserta didik sudah banyak yang mau menanggapi pendapat dari temannya dan peserta didik sudah mulai bisa membuat kesimpulan dari hasil temuan dan diskusi. Karena tujuan dari penelitian sudah tercapai dan kegiatan pembelajaran sesuai dengan rencana dan harapan maka siklus penelitian diakhiri.

Berdasarkan hasil observasi selama melakukan penelitian dengan menerapkan model pembelajaran tipe TPS Plus pada proses pembelajaran khususnya mata pelajaran PKn dapat melibatkan siswa berperan aktif dalam menemukan sendiri fakta konsep, yang diharapkan dapat dikuasai dan dapat melibatkan segenap kemampuan yang dimiliki peserta didik serta dapat memberikan pendapat kepada kelompok diskusinya, sehingga dapat meningkatkan aktivitas belajar peserta didik yang telah mencapai kategori sangat aktif dan hasil belajar peserta didik yang telah mencapai 93,68\%.

Berdasarkan hasil observasi observer di lapangan selama mengamati peneliti yang menerapkan model pembelajaran TPS Plus pada proses pembelajaran khususnya mata pelajaran PKn dapat melibatkan peserta didik berperan aktif dan melibatkan segenap kemampuan yang dimiliki peserta didik sehingga dapat meningkatkan aktivitas dan hasil belajar peserta didik. Hal ini menunjukkan bahwa penerapan model pembelajaran TPS Plus pada mata pelajaran PKn dapat meningkatkan aktivitas dan hasil belajar peserta didik kelas VIII D di SMP Negeri 16 Mataram pada Semester Ganjil Tahun Pelajaran 2016/2017.

\section{Simpulan}

Dari hasil penelitian dan pembahasan dapat disimpulkan bahwa penerapan model pembelajaran TPS Plus dapa tmeningkatkan aktivitas dan hasil belajar peserta didik kelas VIII D SMP Negeri 16 Mataram pada semester ganjil tahun pelajaran 2016/2017. Hal ini ditunjukkan dengan adanya peningkatan aktivitas belajar siswa yang pada siklus I hanya mencapai $62,50 \%$ (skor 20/32) dengan kategori cukup aktif meningkat menjadi $87,50 \%$ (skor 28/32) dengan kategori sangat aktif (ini melampaui indikator kinerja yang ditetapkan peneliti dengan kategori aktif). Sedangkan hasil belajar siswa mengalami peningkatan dari siklus I nilai rata-rata siswa hanya 82,73 dan persentase ketuntasan kelas 55\% meningkat pada siklus II menjadi nilai rata-rata kelas 93,68 dan persentase ketuntasan kelas $95 \%$, ini berarti telah mencapai target ideal $\geq 85 \%$ dari jumlahpesertadidik di dalam kelas (melampaui indikator kinerja yang telah ditetapkan peneliti persentase ketuntasan kelas $\geq 85 \%$ ).

\section{Saran}

Adapun saran-saran yang dapat disampaikan sehubungan dengan hasil penelitian ini adalah sebagai berikut :

- Kepala SMP Negeri 16 Mataram agar dapat mengambil kebijakan tingkat lembaga mengingat manfaat penerapan model pembelajaran TPS Plus cukup besar dapat meningkatkan aktifitas dan hasil belajar peserta didik, hendaknya model pembelajaran ini bias diterapkan lebih intensif lagi pada kelas-kelas yang lainnya.

- Kepada guru PKn dan guru lain hendaknya dapat menerapkan model pembelajaran TPS Plus ini karena daya ingat peserta didik terhadap materi pelajaran lebih lama dan anak lebih aktif mendiskusikan materi yang ditemukan sendiri sesuai dengan materi yang diharapkan. 
- Bagi peserta didik diharapkan untuk menumbuhkan sikap berpikiran kritis, kerjasama antar peserta didik dalam belajar kelompok, mengungkapkan pendapat dan menanggapi pendapat dari temannya serta dapat menghargai pendapat orang lain.

- Kepada penelitilain, disarankan untuk melanjutkan penelitian pada aspek lain yang menentukan aktivitas belajar peserta didik, hasil belajar peserta didik atau motivasi belajar peserta didik karena dengan adanya penelitian ini dapat diketahui factor apa saja yang mempengaruhi peningkatan aktivitas dan hasil belajar peserta didik dan seberapa besar pengaruhnya terhadap keberhasilan belajar peserta didik pada mata pelajaran PKn.

\section{DAFTAR PUSTAKA}

Budiarjo, 2004, Materi Pelatihan Terintegrasi, Jakarta : Depdiknas.

Depdiknas,2007,Pengembangan Kurikulum, Jakarta : Depdikbud.

Djamarah, Syaiful Bahri, 2003, Guru dan Anak Didik dalam Interaksi Belajar, Jakarta: Rineka Cipta.

Halmalik, O, 2003, Pendekatan Baru Strategi Belajar Mengajar Berdasarkan CBSA, Bandung : Sinar Algensido.

Lie, A, 1999, Metode Pembelajaran Gorong Royong, Surabaya ; Universitas Kristen Petra Surabaya.

Mulyasa, 2004, Implementasi Kurikulum 2004 , Bandung, Remaja Rosda Karya.

Nurhadi dan A.G.Senduk,1003, Pembelajaran Kontektual dan Penerapannya dalam $K B K$, Malang ; Universitas Negeri Malang.

Nurkencana, 1983, Evaluasi Pendidikan, Surabaya; Usaha Nasional.

Nurkencana, 1990, Evaluasi Hasil Belajar, Surabaya : Usaha Nasional

Santoso,A,2006, Kamus Lengkap Bahasa Indonesia Untuk SD, SMP, SMU dan Umum, Surabaya; Alumni.

Sugiyono, 2010. Metode Penelitian Kuantitatif Kualitatif dan $R \& D$. Bandung : Alpabeta.

Suharsimi,A,2002,Prosedur Penelitian Suatu Pendekatan Praktek, Rineka Cipta : Jakarta.
Sukmadinata, Syaodih Nana, 2009, Metode Penelitian Pendidikan, Bandung ; PT Remaja Rosda Karya.

Suprijono, Agus, 2009, Cooperative Learning, Surabaya; Pustaka Pelajar.

TukiranTaniredja,Prof.Dr.H,dkk, 2013, Model-Model Pembelajaran Inovatif dan Efektif; Yogyakarta, Sabda Media. 